\title{
Convênio Senado Federal/DASP
}

TERMO DE CONVENIO CELEBRADO ENTRE A GRAFICA DO SENADO FEDERAL E O CENTRO DE DOCUMENTAÇÃO E INFORMÁTICA DO DEPARTAMENTO ADMINISTRATIVO DO PESSOAL CIVIL (DASP) PARA EXECUÇÃO DOS SERVIÇOS DE IMPRESSAีO DA "REVISTA DO SERVICO PÚBLICO", DE LIVROS E PUBLICAÇÕES EM 'GERAL.

Aos vinte e cinco (25) dias do mês de março do ano de mil novecentos e setenta (1970), no Gabinete do Diretor-Geral da Secretaria do Senado Federal e em presença do Dr. Glauco Lessa de Abreu e Silva, Diretor-Geral do Departamento Administrativo do Pessoal Civil, e demais testemunhas, a Secretaria do Senado Federal e o Centro de Documentação e Informática do Departamento Administrativo do Pessoal Civil, no ato, representados, respectivamente, pelo $\mathrm{Dr}$. Evandro Mendes Vianna e pela Senhora Vera da Silva Medeiros, deliberaram assinar o presente convênio, de conformidade com as cláusulas seguintes:

Cláusula Primeira: O Centro de Documentação e Informática do Departamento Administrativo do Pessoal Civil (DASP), doravante neste ato designado por "Centro", se compromete a atribuir à Secretaria do Senado Federal, através de seu Serviço Gráfico, a execução dos serviços de impressão da "Revista do Serviço Público", bem como dos livros e outras publicações que editar, até o limite da parcela de recursos orçamentários para tal fim destinada na respectiva programação financeira.

Cláusula Segunda: Obriga-se a Secretaria do Senado Federal, através de seu Serviço Gráfico, doravante designado por "Serviço Gráfico", a executar os serviços de impressão referidos na Cláusula Primeira, observadas as condiçóes constantes das Cláusulas subseqüentes.

Cláusula Terceira: Os originais da Revista do Serviço Público, livros ou publicações a serem impressos serão entregues, pelo "Centro", ao "Serviço Gráfico" juntamente com ofícios em que se indicará, em cada caso, além do prévio empenho da despesa correspondente, as especificações a serem observadas, inclusive o formato, capa e papel, bem como o preço e o prazo de entrega que, estipulados pelo "Serviço Gráfico", fôr aceito pelo "Centro".

Cláusula Quarta: O "Serviço Gráfico" realizará as duas primeiras revisões de cada número da Revista do Serviço Público, ou obra a ser editada, de acôrdo com o original respectivo que lhe houver sido encaminhado pelo "Centro", ao qual caberá efetuar a última revisão e autorizar definitivamente a impressão.

Cláusula Quinta: O pagamento da importância correspondente à execução dos serviços de impressão, em cada caso, se fará ao "Serviço Gráfico" sob a forma de cheque emitido pelo representante legal do "Centro", contra o Bánco do Brasil S.A., à vista das faturas atestadas e à conta dos recursos orçamentários programados para o respectivo exercício financeiro.

Cláusula Sexta: O presente Convênio vigorará, inicialmente, desde a data de sua assinatura até trinta e um (31) de dezembro de mil novecentos e setenta (1970), podendo ser prorrogado nos exercícios subseqüentes mediante a assinatura de têrmos aditivos, e qualquer das partes poderá rescindi-lo mediante comunicação à outra se ocorrer comprovado inadimplemento ou motivo de fôrça maior.

E por assim acordarem, lavrou-se o presente Convênio que vai assinado em cinco (5) vias pelas partes supramencionadas, em presença das testemunhas abaixo assinadas. - Evandro Mendes Vianna, Diretor-Geral da Secretaria do Senado Federal. - Vera da Silva Medeiros, Diretora do Centro de Documentação e Informática do Departamento Administrativo do Pessoal Civil. - TESTEMUNHAS: Glauco Lessa de Abreu e Silva, Diretor-Geral do Departamento Administrativo do Pessoal Civil - Ninon Borges Seal, Vice-Diretora-Geral Aldministrativa - Wilson Menezes Pedrosa, Superintendente do Serviço Gráfico do Senado Federal. 